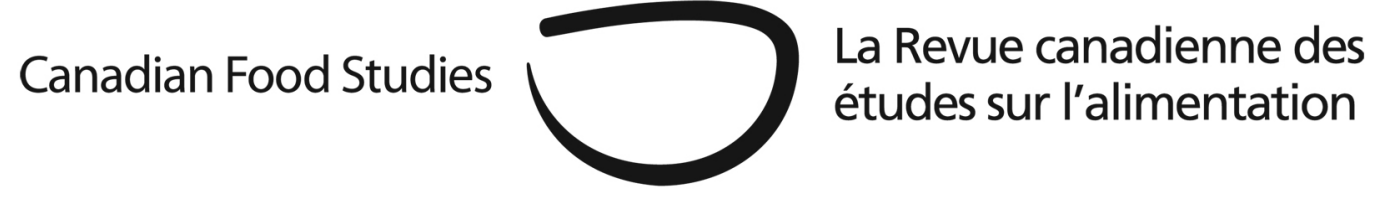

Section $X$

Global food governance in an era of crisis

Special Issue: Mapping the Global Food Landscape

\title{
Global food governance in an era of crisis: Lessons from the United Nations Committee on World Food Security ${ }^{1}$
}

\author{
Nora McKeon \\ Roma Tre University
}

The increasingly destructive impacts that today's global food system visits upon local food provision, biodiversity, and the environment have been highlighted by a number of contributors in this special issue. Viewed through a global governance lens, public responsibility has been progressively sold out to markets and corporations while the front-line actors of food provision-families, communities, and small-scale producers-have been disempowered. Decisions that affect food security are most often taken at tables located behind closed doors, from which the vulnerable are excluded. The global food system is largely orchestrated by powerful corporate, financial, and political actors to serve their own interests.

Now is the time to build better food governance, not only because we are getting very close to the absolute ecological, socio-economic, and political limits of today's dominant system, but also because alternatives do exist. As articles in Section 5 of this issue have illustrated, a diversified and articulated network of different ways of thinking and going about food provision has sprung up, rooted in territories and cultures throughout the world. These solutions are practiced and advocated by increasingly authoritative organizations of peasant farmers, artisanal fisherfolk, pastoralists, indigenous peoples, urban poor, and other constituencies, many of whom recognize themselves in the food sovereignty movement. They are mobilizing around their common experiences at all levels including the global, where they have been instrumental in establishing a unique governance site.

\footnotetext{
${ }^{1}$ Issues raised in this article are addressed in detail in McKeon (2015).
} 


\section{The Committee on World Food Security}

The reform of the existing, but ineffectual, Committee on World Food Security (CFS) in 2009, in response to the 2007-08 food price crisis, was a precedent-setting exercise in opening up intergovernmental process to participation by other actors, with particular attention to those most affected by food insecurity and most active in developing solutions (see McKeon, 2015). Two decades of networking and capacity building aimed at conquering policy space for rural social movements had put them in a position to exploit the political opportunity that the crisis offered and to have effective input within the reform process (Colombo \& Onorati, 2013; McKeon, 2009). The outcome was a forum designed for inclusively debated, paradigm-changing, normative guidance in which these constituencies are full participants, where the right to food is the mission, and where expertise is recognized to reside in producers and practitioners as well as researchers and academics.

When the "new" CFS was heralded with a standing ovation by the participants at the final meeting of the multi-actor assembly in which the reform had been negotiated, there might have been a momentary temptation to think that the global food governance problem had been "solved." Of course it had not, but it was an important step in the right direction. Now, five years later, the experience of the CFS becomes a vantage point from which to revisit the explicit and implicit assumptions that informed its design and to survey what else is needed. This article considers some key lessons learned from a civil society perspective.

\section{Lessons}

One lesson is that global governance can only be effective and equitable if it is built from the bottom up and incorporates the democratization of food provision at all levels; multiple examples of this around the world have demonstrated that it can happen and is happening. Indigenous peoples are an inexhaustible source of knowledge about different ways of governing food, but there are others. Extended family farms in West Africa, for example, have introduced family assemblies as spaces in which patriarchy can be challenged pacifically and women and young people can pursue their objectives. Even in the global North, where the corporate food system is most strongly entrenched, community-supported agriculture schemes and municipal food councils are spreading (Snipstal, this issue). They constitute decentralized laboratories in governance that liberate the energy of people, on whom the dominant corporate system had previously had a soporific effect.

Under pressure from citizens, sub-national governance is daring to challenge national jurisdiction and global rules on issues like genetically modified organism (GMO) labelling and public procurement. Regional economic bodies such as the Latin American Mercosur and the Economic Community of West African States (ECOWAS) are governance sites to which social 
movements can have more immediate and continuous access than at the global level. Peoplepowered linkages — not only vertical but also horizontal — are one aspect of what has to happen to build better food governance globally. The CFS has a mandate to make connections with regional and national food policy spaces, however not enough has been done thus far by either the official or the civil society actors of the committee. A more legitimate group of people may be in the room at Food and Agriculture Organization (FAO) headquarters where the CFS meets, but ownership of the political work they are doing there is insufficiently broad and deep, nor is it adequately linked to the reality of people's lives and struggles.

A related lesson is that the prospect of instituting a single global organ that could dictate binding rules on all aspects of food provision is unlikely, and probably not even desirable. ${ }^{2}$ What civil society actors prefer, it seems increasingly clear, is a governance system that can produce and enforce authoritative guidance and promote policy coherence globally, but at the same time reinforce public policy space and accountability at levels where inclusion of the vulnerable is most feasible and where diversity can flourish (see Narula, this issue). This means turning the dominant top-down direction of the transnational governance approach of the past couple of neoliberal decades on its head. Interestingly enough, the best-armed enforcer of global regulations - the World Trade Organization (WTO) — is suffering breaches of its authority on the terrain of food security (see Murphy, this issue). For example, the global food crisis has prompted some countries to directly outsource food provision via land grabbing, thus contravening the goal of WTO trade rules (McMichael, 2013). And in August 2014, during the final round of the negotiations on principles for responsible agricultural investment (RAI), the government of India took a timid step to bring its claims for the right to defend its national food security strategy-which had been repulsed just days earlier in the WTO Council of Ministersinto the CFS (see Kripke, this issue). India's stance was a contribution towards imagining a world in which the right to food can trump trade, rather than the contrary, and towards combatting forms of regime complexity that privilege the powerful and well resourced over the vulnerable (Margulis, 2013).

Many more such steps are needed. Better linkages between the CFS and other global forums like the UN Human Rights Council are also needed. The UN Human Rights Council has succeeded in getting processes underway to defend peasants' right and regulate transnational corporations (Claeys, 2014; Monsalve Suárez, 2013). Outreach to less congenial forums is equally important. The CFS was built on an implicit assumption that a global governance system can be based on articulation and coherence seeking, rather than on hierarchical domination, and on normative rather than sanction-based enforcement. Instead, experience demonstrates that defenders of the dominant global corporate-led food system are propagating fragmentation as a means of weakening the CFS' mandate as the foremost food security forum. The Second

\footnotetext{
${ }^{2}$ Some pro-food sovereignty authors tend to support this direction by, for example, recommending a pro-poor redistributive global institution (Akram-Lodhi, 2013), while others draw attention to the implication that “transferring too many regulatory powers to the international level would undoubtedly entail trade-offs for people’s self-determination” (Monsalve Suárez \& Aubry, 2014, p. 24).
} 
International Conference on Nutrition, the post-2015 agenda, and the post Rio+20 market-driven work on the green economy are strategic discussions, which ought to-but do not-benefit from CFS guidance regarding implications for food security and the right to food. ${ }^{3}$ On the contrary, the inviolability of fortresses where the neoliberal cohorts are strong - like the WTO - is brandished as a doubtfully valid argument for refusing to let the CFS "tread on their territory" from a right-to-food perspective.

Another candidate for further reflection concerns the appropriate political decisionmaking practices for global food governance. The CFS reform was the response to the food price crisis advocated by social movements and Group of 77 (G77) countries in 2009 because it privileged inclusive political decision making over technical-managerial fixes (as in the UN High Level Task Force on the Global Food Security Crisis) or Group of Eight (G8) smoke-screening (as in the Global Partnership on Agriculture, Food Security and Nutrition). This preference is not being questioned today, but the tendency for negotiated consensus to sink towards an only marginally useful lowest common denominator is painfully evident. The higher the political stakes, the lower the negotiated level of consensus seems likely to be. Consensus is not necessarily conducive to social and political change. Might it be preferable-in situations where interests are so diverse and power imbalances so extreme-to return to the time-honoured practice of voting? The outcome might not be significantly different on key issues, but accountability could be heightened. In the run-up to final decision making, as well, it is useful to highlight differences and subject them to debate. Statements of dissent in reports of the CFS' High Level Panel of Experts (HLPE) that provide background for CFS sessions can be instructive for policy makers and can oblige them to assume their decisional role. A deeper and more nuanced discussion can help them to better understand the stakes of what they are negotiating. How can the right balance between discursive deliberation and political decision-making be achieved?

One area of CFS progress is precisely that of significantly shifting the terms of the debate. In five short years, the CFS has come to officially acknowledge that small-scale producers are the main investors in agriculture and produce some 70 percent of the food consumed in the world. This contradicts the normalizing discourse that large-scale industrial agriculture is the only hope for feeding the world's growing population (Akram Lodhi, this issue). Crucially, the CFS has deconstructed "the market," recognizing that all markets are not the same and that not all are beneficial for small-scale producers and local economies. Highquality HLPE reports contribute to this paradigm shift, as does direct engagement by people's organizations whose reality checks cannot be ignored.

This broadening of horizons does not necessarily translate directly into the terms of negotiated normative guidance. The outcome of the RAI negotiations is weaker than those of

\footnotetext{
${ }^{3}$ Nonetheless, promising efforts are now underway to broker a long overdue marriage between nutrition and agriculture in the context of the CFS. (See Right to Food and Nutrition Watch 2015.) On the other hand, there is growing interest in taking the CFS/CSM as a model for governance of the post-2015 agenda, with the danger of abstracting it from the process of social movement mobilization that constitutes a basis of its legitimacy.
} 
earlier policy discussions on related topics (McMichael, this issue). Along similar lines, a key piece of the CFS reform was the hard-won agreement to develop a Global Strategic Framework (GSF) for attaining food and nutrition security and the right to food. The GSF was conceived by civil society advocates as a way of progressively assembling CFS deliberations to shift the paradigm from liberalization towards the right to food, and as a tool to promote accountability. It has not yet fulfilled these aspirations. The monitoring function of the CFS is proving to be one of the most difficult to put into practice because of a governmental allergy to accountability. Yet it remains an essential piece of what would be necessary to build better global food governance. How to carry it forward constitutes another fruitful terrain for reflection.

What is actually done with normative guidance once it has been promulgated is a related issue, and another for reflection. If CFS outcomes cannot be appropriated by the base, they will remain ethereal abstractions and social movement engagement will wither. The limitations of "voluntary" guidelines have been denounced. Now, however, it is suggested in some quarters that it is not so much an issue of hard- versus soft-law per se, but rather of the overall dynamics of power and law in developing effective ways to control the powerful (Monsalve Suárez \& Aubry, 2014). Non-binding, voluntary codes are not all the same. Instruments like the CFS tenure guidelines are potentially suited to being transformed into strong, enforceable, national regulation since they result from inclusive decentralized consultation and negotiation, which has incorporated many of the concerns of those most affected. The imperative of bringing CFS norms to bear on national realities takes us back to the initial acknowledgement in this article that better global food governance is wedded to bottom-up democratization of decision-making. It also shines a spotlight on the paradoxical situation of states - currently among the worst offenders in promoting short-sighted and self-seeking objectives, and yet a basic building block for accountability and defense of citizens' collective rights (Narula and Claeys, this issue).

Finally, who ought to be in the global governance room, and with what roles? A largely unquestioned string of illogical thinking starts off with the truism that the corporate private sector has enormous influence on food security and hence has to be taken into account in seeking solutions to hunger and malnutrition. That may be the case, but how should it be taken into account? Should the corporate private sector be "in the room" on the same footing as civil society, as in the CFS, helping to define standards that are expected to defend the right to food of the world's population and the ecological and climatic health of the planet? The in-the-room champions argue that if corporations do not participate in framing normative guidance they are not likely to respect it, but experience with corporate social responsibility points in a different direction (Clapp \& Thistlethwaite, 2012). As West African peasant leader Mamadou Cissokho has put it, "We don't want 'responsible investors'. We want a legislative framework that protects us effectively and investors who are obliged to respect the law” (personal communication, 2012). Unregulated public-private partnerships are no substitute for public policies. 


\section{Conclusion}

Eight years after the 2007-08 global food price crisis, we are in an interesting place as far as prospects for global food governance are concerned. On the one hand, the food sovereignty movement is progressively building up its potential to help fragment the global hegemony of the corporate food system and reconstitute a territorially rooted and governed approach to food provision (see Desmarais and Wittman, this issue). On the other hand, the advent of the CFS has created the prospect of a global forum that might actually support, rather than squash, initiatives from the grassroots. The fact that the CFS is under attack today from those who have nothing to gain from better food governance is an indicator of its success. It is an incitement to us to defend it, including by critiquing its weaknesses and addressing its limitations.

This article has identified some of the areas in which further research would be welcome. There is an impelling need for serious, documented assessments of "multi-stakeholderism" as an approach to governance that includes actors other than states alone, at all levels. What requirements have to be respected in order to recognize the separate identities and responsibilities of different actors, maintain governmental accountability, empower the vulnerable, and address power imbalances and corporate conflicts of interest? Achieving a more sensitive understanding of the dynamics of multiscalar governance is another important research objective related to the vision of a world organized around regionally based, ecologically resilient agrifood systems. Verifying the conditions under which global discursive victories and norms adoption can support people's local struggles to defend their rights is essential to judge the pertinence of social movement engagement in international arenas, as is strategic reflection on how best to address forum fragmentation from a human rights perspective. Going beyond the "what" to the "how," the challenge_-in the spirit of the reformed CFS and building on experience in areas like the fight against land grabbing-is to devise methodologies of inquiry that allow the different forms of knowledge and experience of academics, practitioners, and social movements to enter into dialogue and enrich one another.

\section{References}

Akrah-Lodhi, A. H. (2013). Hungry for change: Farmers, food justice and the agrarian question. Halifax: Fernwood Publishing.

Cissokho, M. (2012). Letter to His Excellence Yayi Boni, President of the African Union. Retrieved from http://www.europafrica.info/en/news/foos-security-a-letter-to-thepresident-of-the-african-union 
Clapp, J. \& Thistlethwaite, J. (2012). Private voluntary programs in environmental governance: Climate change and the financial sector. In Schneider, R. (ed.). Business and Climate Policy: The Potentials and Pitfalls of Private Voluntary Programs (pp. 43-47). New York: United Nations University Press.

Claeys, P. (2014). Food sovereignty and the recognition of new rights for peasants at the UN: A critical overview of La Via Campesina's rights claims over the last 20 years. Globalizations, online.

Colombo, L. \& Onorati, A. (2013). Food: Riots and rights. IIED, CIC, FIRAB. Retrieved from http://www.firab.it/site/wp-content/uploads/2013/09/foodrights_aw.pdf

Margulis, M. (2013). The regime complex for food security: Implications for the global hunger challenge. Global Governance, 19, 53-67.

McKeon, N. (2009). The United Nations and civil society: Legitimating global governancewhose Voice? London: Zed.

McKeon, N. (2015). Food security governance: Empowering communities, regulating corporations. London: Routledge.

McMichael, P. (2013). Food regimes and agrarian questions. Halifax: Fernwood Publishing.

Monsalve Suárez, S. (2013). The human rights framework in contemporary agrarian struggles. Journal of Peasant Studies, 40(1), 239-290.

Monsalve Suárez, S. \& Aubry, F. (2014). Rethinking the voluntary vs. binding divide: A reflection after 10 years of the voluntary guidelines on the right to food. Watch 2014, 3 . Retrieved from http://www.rtfnwatch.org/uploads/media/Watch_2014_Article_3_Voluntary_vs._Binding_Instruments_E NG.pdf

Right to Food and Nutrition Watch 2015 (in press). Available at: http://www.rtfn-watch.org 